\title{
FILMAR A CONTRAPELO: EL CINE DE HELVIO SOTO DURANTE LA UNIDAD POPULAR
}

\author{
FILMING AGAINST THE GRAIN: THE CINEMA \\ OF HELVIO SOTO DURING THE POPULAR \\ UNITY GOVERNMENT
}

\section{TOMÁS CORNEJO ${ }^{1}$}

\section{RESUMEN}

Helvio Soto mantuvo una relación problemática con sus colegas cineastas identificados con el Nuevo Cine Chileno al terminar la década de 1960. En los años venideros rodó tres largometrajes argumentales sobre la Unidad Popular. Con los dos primeros pareció distanciarse de los realizadores comprometidos con el gobierno de Salvador Allende, ya que exhibía algunas contradicciones de éste. Sin embargo, ese distanciamiento no fue tal y tuvo que ver con una intención política de llegar a otro público. Asimismo, las objeciones que suscitó la obra de Soto provinieron de la experimentación formal en la que se sustentó, al poner en tensión los terrenos del cine de ficción y del documental.

Palabras clave: Helvio Soto, Nuevo Cine Chileno, Unidad Popular, cine político, argumental, documental.

\section{ABSTRACT}

Helvio Soto had a strained relationship with his fellows filmmakers identified with the New Chilean Cinema at the end of the 1960s. In the following years he shot three fiction feature-length films about the Popular Unity. The first and the second ones seemed to put some distance from his colleagues committed to Salvador Allende's government because they exposed some of its contradictions. However, this distance was only apparent, and was due to a political intention to reach another audience. Similarly, the objections that Soto's work provoked came from his formal experimentation, which

${ }^{1}$ Doctor en Historia, El Colegio de México. Investigador Escuela de Historia, Facultad de Ciencias Sociales e Historia, Universidad Diego Portales, Santiago de Chile. Correo electrónico: tomas.cornejo@udp.cl 
created a tension between the territories of fiction and documentary cinema.

Keywords: Helvio Soto, New Chilean Cinema, political cinema, fiction film, documentary film.

Recibido: 13.07.12. Aceptado: 26.04.13.

\section{EN LOS MÁRGENES DE LOS “NUEVOS CINES”}

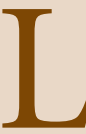

A DENOMinación Nuevo Cine Chileno ha resultado ser un tanto imprecisa. Surgido al amparo del Nuevo Cine Latinoamericano que tu-

viera en Viña del Mar en 1967 ocasión de hacer dialogar y reflexionar

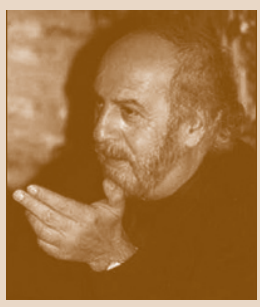

M. Littin

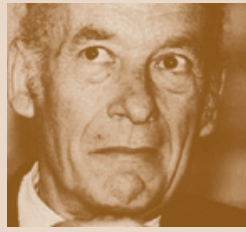

A. Francia

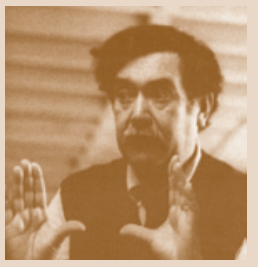

R. Ruiz

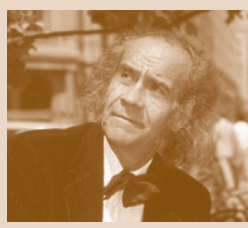

H. Soto a sus exponentes, la vertiente chilena de éste fue más difusa en sus inicios. Se ha llegado a cuestionar su propia existencia, alegando que quienes habrían sido sus primeros exponentes (Miguel Littin, Aldo Francia, Raúl Ruiz y Helvio Soto) no tuvieron mucho de común entre sí y que, además, la valoración retrospectiva de su obra ha obliterado que en forma paralela se siguieron produciendo en el país cintas situadas en las antípodas cinematográficas (Cavallo y Díaz, 2007). Otros autores, al contrario, sostienen que la práctica fílmica pergeñada en Chile a fines de la década de 1960 se convirtió en el modo dominante de hacer cine, de mano de la inarticulada aun cuando fructífera política cultural de la Unidad Popular (Silva y Raurich, 2010).

A partir del balance posterior del cual han participado algunos de sus cultores, puede afirmarse que el Nuevo Cine Chileno no fue tanto un movimiento como la coincidencia de intereses estéticos, políticos y sociales de un puñado de jóvenes (lo generacional es otro factor importante) que trataba de hacer cine en un país carente de tradición fílmica y que tuvo una expresión oficial recién en 1970 con el Manifiesto de cineastas de la Unidad Popular, lo que implica otra serie de problemas. Según Miguel Littin, uno de sus redactores, pese al contenido programático del texto, sus adherentes se opusieron a aplicarlo mecánicamente o hacerlo extensivo a todos los cineastas (Primer Plano, 1972b).

Un elemento común a quienes se reconocieron dentro del paraguas del Nuevo Cine Chileno fue la voluntad de cambiar el modo de filmar, tanto en obras documentales como de ficción. "No es una cuestión tanto de lenguaje cinematográfico como de contenidos", indica Jacqueline Mouesca (1988), para quien "estos nuevos cineastas saben más de cine que los anteriores, pero además son, en general, más cultos; todos ellos examinan la historia oficial y la realidad de su entorno con una mirada crítica", y buscan integrar "los problemas sociales y la identidad nacional en la creación artística" (36). 
$\mathrm{Al}$ aventurarse en la construcción de un cine con nuevos horizontes expresivos compartieron sin duda las inquietudes de otros cineastas del continente. Esto resulta patente en un punto en particular, los debates sobre quiénes, cómo y para quiénes había de hacerse cine, además de la pregunta por su utilidad en un contexto revolucionario (Getino y Velleggia, 2002). A ello se agrega que, como ha sugerido Ana López (1990), algunos realizadores latinoamericanos desarrollaron un cine paródico -en su sentido etimológico de contrapunto-, a través de los múltiples desplazamientos que efectuaron en los géneros cinematográficos hasta entonces aceptados. Sus búsquedas llevaron a un cine propio, contrahegemónico, como lo requería la articulación descolonizadora en el plano cultural.

El caso chileno fue de todas maneras particular. Carentes de una industria fílmica o de una gran tradición cinematográfica, la elección de Allende auguró buenas expectativas para los cineastas nacionales. Estas, sin embargo, no se plasmaron del todo, ante la incapacidad de dotar a un organismo centralizado como Chile Films de las facultades legales, administrativas y ejecutivas necesarias para llevar a cabo una producción sostenida (Guzmán, 1974). La misma indeterminación o falta de una política cultural y de canales para implementarla llevó, por otra parte, a un cierto grado de apertura creativa. Resulta difícil hablar, como se ha hecho, de un "cine de Allende" o de un "cine de la U.P." (Bolzoni, 1974), ya que ni siquiera existió uniformidad en el terreno del documental, cercano al gobierno por sus entidades productoras y la ideología de sus realizadores. La cantidad de largometrajes argumentales que se concretó fue por el contrario muy pequeña. Y fueron casi invariablemente cintas de temas contingentes, acuciadas por la realidad sociopolítica. Entre otras, Ya no basta con rezar (1972), de Aldo Francia, y Operación Alfa (1972), de Enrique Urteaga, que no obstante tomar problemas vivos de la realidad extra-fílmica (el compromiso político de los cristianos y el asesinato del general Schneider, respectivamente), el mundo del cine juzgó tardíos en su exposición (Primer Plano, 1972d).

La labor de Helvio Soto (Santiago, 1930 - París, 2001) se enmarcó en ese tipo de cine, atento al devenir de los acontecimientos, crítico del pasado y jalonado por el ritmo de los hechos políticos. Con Voto+Fusil (1971), Soto dio inicio a un examen agudo de las contradicciones del proceso de construcción del socialismo chileno. La cinta expuso la disyuntiva de la izquierda entre la vía electoral y la vía armada, cuestión palpitante al momento del estreno, a menos de un año del triunfo de Allende. La película enaltece la figura de los militantes de la izquierda insurreccional por su compromiso ético con la transformación radical de la realidad. Estos son encarnados por

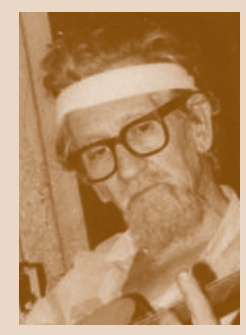

E. Urteaga 


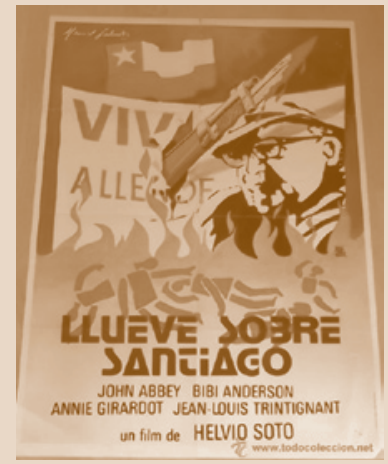

un personaje que -según todas las señas, ya que no se lo nombra de forma explícita- pertenece al Movimiento de Izquierda Revolucionaria (M.I.R.), opuesto al protagonista, militante comunista.

Soto emprendió con este largometraje una experimentación con el lenguaje fílmico inseparable de los temas que propuso a nivel del relato. Llevó más allá la exposición de las ambigüedades del gobierno y los partidarios de la U.P. en su siguiente trabajo, La metamorfosis del jefe de la policía política (1973), que no alcanzó a estrenarse en el país. Exhibido meses después del golpe de Estado en Francia, las invectivas en su contra fueron varias y provinieron sobre todo de cineastas chilenos y latinoamericanos comprometidos con la resistencia cultural a la dictadura. Se le atribuyó "confusionismo ideológico" y "oportunismo político que sirve los intereses del colonialismo cultural", por lo que el filme -y en parte su autor-fue anatemizado, en tanto "no expresa ninguna de las posiciones del movimiento revolucionario chileno", como se lee en la Declaración de cineastas latinoamericanos en el Encuentro Cinematográfico del Tercer Mundo, que tuvo lugar en Argelia en 1974 (cit. en Mouesca, 1988: 46).

Con su tercer largometraje referido a la U.P., Llueve sobre Santiago (1975), el director volvió a ser admitido en el seno de los actores culturales de la izquierda chilena, entonces exiliados o refugiados en distintos países y activos propagandistas en contra del régimen pinochetista, espíritu del cual participa la mencionada cinta. Con ella Soto culminó una dispar trilogía sobre el proceso histórico de la Unidad Popular; dispar por los resultados fílmicos que alcanzó con las dos primeras, experimentales y arriesgadas en el uso del lenguaje visual, pero también por la mirada crítica que ensayó en ellas sobre un proyecto político del cual él mismo era firme partidario. Lo que en Llueve sobre Santiago se convierte en una oda a la U.P., en Voto + Fusil y La metamorfosis del jefe... había sido una crítica cáustica. Pero fue una crítica ejercida desde dentro, con lealtad hacia el proyecto socialista y en especial con apego a la necesidad de forjar nuevos parámetros para la expresión fílmica, algo que Soto compartía con sus colegas chilenos y latinoamericanos.

\section{UN BURGUÉS NARRANDO LA CONSTRUCCIÓN DEL SOCIALISMO}

Caliche sangriento (1969), segundo largometraje de Soto, fue considerada una de las cintas que dieron inicio al Nuevo Cine Chileno. Éste y sus siguientes filmes participaron de un campo cultural en pugna con el impe- 
rialismo y atravesado por trincheras ideológicas, sin una institucionalidad acorde a los deseos de los cineastas, carentes de un lenguaje visual afinado y aparentemente divorciados del público.

Enfrentado a tales problemas, el posicionamiento discursivo de Helvio Soto fue inéditamente sincero. Al contrario de aquello que propugnaban sus compañeros de ruta, abandonó el empeño por llegar a un público masivo. Fue una decisión contradictoria, dada su trayectoria que lo llevó de la novela al cine, convencido del impacto limitado de la literatura en países con altas tasas de analfabetismo (Primer Plano, 1972a: 18). Y fue además una decisión polémica, en vistas del debate que animaba el mundo cultural chileno, la mayoría de cuyos actores abogaba por llegar a un público lo más amplio posible. Ahí radicaba la utilidad del cine como palanca movilizadora del espectador hacia la toma de conciencia de la realidad social y su consecuente actuar para cambiarla, en sintonía con las propuestas del "tercer cine" y del "cine imperfecto" (García Espinoza, 1969 y Silva y Raurich, 2010). Como indicó el propio Soto: "Una de las mayores objeciones [...] que yo le haría a gran parte del cine latinoamericano, y aun a mi propio cine, es que se limita a tener una actitud un poco plañidera. Vale decir, refleja la pobreza, la miseria local, sin inducir a una participación más efectiva por transformar la realidad" (Primer Plano, 1972a: 6).

Para Miguel Littin, quien dirigió Chile Films durante el primer año de gobierno de la Unidad Popular, el cine, además de una industria, era "un instrumento para educar a las masas". Reconociendo de hecho cuán difícil era montar el sustento material para un desarrollo fructífero de la actividad, Littin se inclinaba por creer "que primero hay que aprovechar, en la actual coyuntura nacional, el dividendo ideológico que la cinematografía pueda rendir" (Primer Plano, 1972b: 13).

Helvio Soto concordaba con ese planteamiento, pero fue mucho más escéptico respecto a los alcances de la cámara como arma de combate. Un problema básico lo constituía el capital cultural de la población, ese esquivo e idealizado espectador promedio al cual se quería apelar con la proyección de fotogramas en una pantalla. En opinión de Soto, "por desgracia, nuestro público entiende la mínima parte de las cosas que uno quiere decir", en lo que se observaba una falta "de comprensión de las masas, no sólo del lenguaje cinematográfico sino de los temas políticos también” (Primer Plano, 1972a: 10). Por tal razón, pero reconociendo antes que nada sus limitaciones personales como cineasta y productor de un mensaje político, Soto adoptó una actitud pesimista.

Puesto ante la disyuntiva de filmar pensando en el gusto del público 


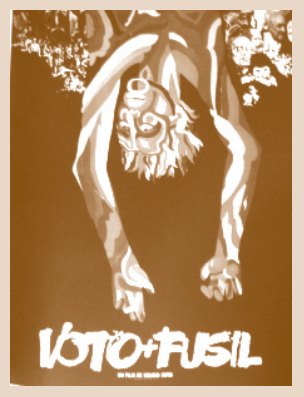

europeo sofisticado y proclive a la lucha anticolonial (Voto+Fusil se exhibió en Cannes, con críticas mayoritariamente favorables) o de contribuir en la creación de un cine popular nacional, el director señaló: "En alguna medida he renunciado a la temática popular [...]. Yo puedo sentir adhesión por mi país, puedo estar a su favor si él quiere, luchar en contra de la injusticia que soporta. Pero eso no significa que yo, cineasta burgués, calificación que acepto, vaya a decir: 'yo entiendo cómo es el pueblo, sé cómo habla, cómo vive, sé lo que desea, lo que aspira'. Eso es mentira" (Primer Plano, 1972a: 14). Como aclaró en la misma entrevista, optó por cultivar "una temática burguesa, para un determinado público que tiene un cierto manejo de los elementos culturales de este tiempo y en nuestro país. Reconozco que dejo afuera, en la calle, a inmensos sectores. Pero, ¿qué quieres? Al dirigirme a determinado público chileno, minoritario seguramente, que constituye círculos de influencia, digo profesionales, intelectuales, estudiantes [...], con los cuales tenemos la misma alienación" (Primer Plano, 1972a: 15).

Frente a tal distanciamiento hay que observar dos cosas. La primera, que en él tuvo injerencia un sentimiento de desazón respecto a la audiencia masiva que Soto experimentara un par de años antes con Caliche sangriento. Este filme fue censurado en un primer instante por las autoridades, para permitir después su exhibición, aunque la magra respuesta del público, no tanto por la cantidad, sino por la calidad de la misma, decepcionó al director (Soto, 1980). Con esta película de lenguaje ágil, creada con algunas concesiones a la moda fílmica, la reacción masiva terminó sin embargo siendo contraria. El motivo, el tema de la cinta y la clara intención de su realizador de atacar un mito, el patriotismo del ejército chileno, ejemplificado con un pasaje ficticio de la Guerra del Pacífico.

La segunda observación relativa a la posición adoptada por Soto en plena U.P. se vincula con las estrategias comunicativas decididas por artistas, intelectuales y otros productores de bienes simbólicos en directa relación con sus adhesiones políticas. En Chile se dio un debate amplio respecto a cuáles debían ser las políticas culturales del gobierno de Allende, toda vez que éste se proponía una gran transformación, pero carecía de un aparato institucional para hacerla andar. En el examen minucioso de la realidad chilena, con el concurso de los cientistas sociales, se constató que la conciencia de los sujetos populares estaba moldeada por los productos de consumo masivo, dentro de los cuales el cine y, crecientemente, la televisión, eran gravitantes. Mientras que algunos propugnaron la existencia aún viva de un núcleo irreductible del alma popular, otros desconfiaron de ello, dada la penetración ideológica tras décadas de cultura de masas (Bowen, 2008). 
Los cineastas estaban conscientes de un problema de tal magnitud. Durante los breves años de gobierno popular, quienes laboraban desde el oficio del cine en distintos niveles de decisión adaptaron sus opciones ideológicas a las tácticas del enfrentamiento político. Es aquí donde el camino emprendido por Helvio Soto resulta acorde con las vicisitudes de ese período. Porque si bien Voto+Fusil, "es la apología del mirismo", como indicó un crítico de la revista Ercilla (1971: 47), su público objetivo no eran ni los campesinos, ni los pobladores, ni los obreros (entre los cuales el M.I.R. encontró una base de apoyo).

Las capas medias ilustradas a las que apeló Soto con este filme y con el que rodó a continuación, constituyeron un público objetivo que el cine producido al alero de la U.P. buscó con afán. En parte, fue un público que debió construirse. Porque si bien la audiencia masiva, las clases trabajadoras urbanas, fueron los espectadores ideales que los realizadores tenían en mente, las veleidades de la realidad política llevaron a una diversificación de las propuestas comunicacionales. Como es sabido, fue el documental el que tuvo mayor auge durante el gobierno de Allende, al cabo de cuyos primeros doce meses, sin embargo, la evaluación no fue positiva. El crítico Mariano Silva (1972) encontró en los informativos y noticieros cinematográficos una serie de defectos. Con ellos, se "daba cuenta de la marcha de la revolución chilena mostrando al país en fórmulas visuales que copiaban tics ya superados por la cinematografía cubana [...]. Resultado: atizamiento de odios entre gobierno y oposición y desprestigio para la industria oficial del cine".

No menos severo fue Patricio Guzmán, que a la sazón ya había rodado El primer año. Para Guzmán, los noticieros producidos por Chile Films caían en el panfleto, y promediando 1972 no creía justificado seguir realizándolos. Dada la creciente polarización política, vislumbraba que tales "documentales combativos" debían tener como destinatarios los sindicatos y otras organizaciones o agrupaciones proclives al gobierno. En cambio, para el público cuyo contacto con el cine se daba en las salas comerciales convencionales, "no cab[ía] la batalla ideológica directa, sino indirecta". En dichos circuitos de distribución y consumo del producto fílmico, que implicaban una cierta predisposición de la audiencia, así como un horizonte de expectativas creado durante décadas, de acuerdo a Guzmán, lo apropiado era entregar "cierto tipo de documentales que proyecten $[\ldots]$ una imagen de seriedad del gobierno hacia las capas medias" (Primer Plano, 1973: 33).

Esta diversificación de públicos y circuitos culturales se concretó sólo 
a medias. Tal vez en la filmografía de Helvio Soto fue más notorio, ya que al estratégico desplazamiento del público al que buscó llegar, el director sumó el desplazamiento del foco narrativo. La delineación sociocultural de los protagonistas de sus cintas resultó clave. Vistos en conjunto, los largometrajes de corte político de Soto, entre los cuales puede incluirse Caliche sangriento, tienen un rasgo común. Todos sus personajes principales pertenecen, justamente, a la clase media profesional e ilustrada: un abogado (en Caliche Sangriento), un director de cine (Voto+Fusil), un sociólogo ( $L a$ metamorfosis del jefe...) y un periodista (en Llueve sobre Santiago).

Los comentaristas de la época notaron que justamente la construcción de los personajes era uno de los puntos débiles del trabajo del realizador. Además de ser demasiado esquemáticos, señalaron que no ahondaba en su potencial vida interna. Esto último fue más acusado en el caso de Voto+Fusil, donde sí hay un delineamiento de las fuerzas y contradicciones que animan al protagonista, cuya subjetividad se recupera en un trabajo de memoria expuesto con varios flash-backs. Aunque eso ocurre durante la primera mitad del filme, que se concentra luego en el presente narrativo, en el cual todo se acelera y parece no haber tiempo para el recuerdo, sino para el verbo y la acción. Ésta última, originada en aquél, fruto de una palabra que es ejercicio de la razón.

A cada personaje protagónico Soto opuso un antagonista verbal e ideológico: el capitán que enfrenta al abogado durante la Guerra del Pacífico; el cercano mirista admirado por el cineasta que por años ha militado en el P.C.; el cínico funcionario del gobierno de la U.P. que tiene más información que el propio jefe de la policía política. Las parejas así conformadas llenan largas secuencias del cine de Soto. No son las mejores como expresión cinematográfica, sino instancias en las que el director pone en juego un discurso reflexivo y dialéctico. Resultan, por otra parte, pares antagónicos efectivos para hacer avanzar el relato. En tanto se trata de personajes verbales, razonantes y dialogantes, vistos desde la distancia temporal son asimismo miméticos con el entorno real de la década del 60 y del 70 en el que la discusión y el debate constituían un hecho social practicado habitualmente.

Los alcances de estos desplazamientos narrativos informaron la ideología de los largometrajes de Helvio Soto. Estos, referidos al aquí y al ahora, eran altamente funcionales a la necesidad de comprender y explicar una realidad social que cambiaba de manera vertiginosa para no volver atrás. Aquello que sus personajes efectúan es una aprehensión del cambio histórico, nada menos que cuando éste tenía lugar. Ya que el universo diegético 
de sus cintas remite a la realidad extrafílmica, los personajes que las pueblan se convierten en atribulados cronistas de un tiempo que tenía todas las marcas de lo histórico.

Siguiendo esta lógica, si con sus cintas Soto trazó un ejercicio muy temprano, inmediatista, de escritura historiográfica desde el cine (Rosenstone, 1997), que arranca en 1970 y acaba abruptamente tres años después, lo que se insinúa en esa escritura es que los protagonistas del proceso histórico son los intelectuales. Y esa lectura de la producción fílmica de Soto sí que contraría el discurso dominante entre la cultura de la izquierda chilena y latinoamericana. Es un problema sobre el que se volverá más adelante, porque requiere incorporar lo relativo al manejo del lenguaje cinematográfico. De una parte, su filmografía apunta a asignarle historicidad nada más que a ciertos grupos del entramado social. Aunque, en último término, no equivale a historicidad en tanto capacidad de acción, sino exclusivamente como capacidad de comprensión. Porque los protagonistas de sus películas son lúcidos - para usar una palabra de la época, ya desgastada-, pero también bloqueados, imposibilitados de pasar a la acción y ejercer el cambio. Mientras ellos observaban, otros, como plantearon sus mismos largometrajes, fueron plenamente conscientes de su capacidad de actuar. Y actuaron.

\section{NI DOCUMENTAL NI FICCIÓN: HACIA UN DOCUMENTO FÍLMICO. LA UNIDAD POPULAR Y LO HISTÓRICO}

Como quedó apuntado, Voto+Fusil cayó muy mal entre los partidarios de la Unidad Popular, en particular entre los comunistas (Bolzoni, 1974: 151). Según expresara el propio Soto (Primer Plano, 1972a: 23), desde las filas del P.C. se entendió la relación entre los personajes centrales de la cinta como una censura lanzada desde la pantalla a la manera en que buena parte de sus militantes había labrado su compromiso político. Sin embargo, para el director se trataba más bien de una cuestión existencial y no de plantear o defender una determinada tesis política (Primer Plano, 1972a: 24). El apego a la teoría y el desapego de las necesidades de las clases subordinadas parecía contrastar con un imperativo ético convertido en acción, llevado a la práctica por los jóvenes que, a la hora de decidir, estaban prestos a tomar el fusil y no a marcar el voto.

La crítica especializada emitió varios reparos a la cinta, enfocados en la propuesta estética del director más que en la trama. Mientras que hubo coincidencia en resaltar el dominio del oficio que aquél imprimió a la pe-

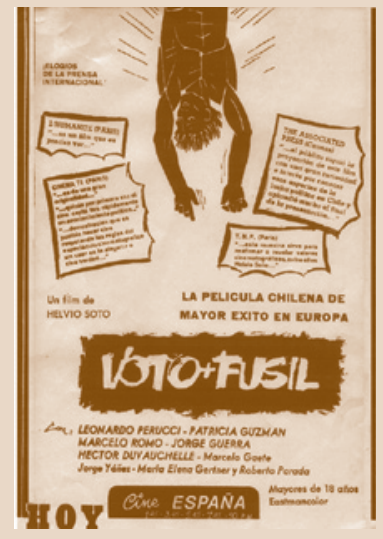

$21 \quad$ Atenea 508 
lícula, lo que auguraba un salto cualitativo respecto a las producciones nacionales de un lustro antes, se debatió largamente su apuesta cinematográfica. ¿En qué consistió esta?

"La mitad de este filme es una ficción. La otra mitad reposa en la realidad. Entonces cada uno decidirá qué es realidad y qué es ficción. Así será posible que para unos todo sea ficción y que para otros todo sea realidad". Con estas palabras, proyectadas en sucesivos anuncios, comienza la película. Es una advertencia a los espectadores, a la vez que una clave de lectura. Cuando fue exhibida, si bien hubo acuerdo en qué era ficción y qué realidad, la manera de registrar y exhibir ambos campos cinematográficamente resultó controvertida.

Situada temporalmente en los meses inmediatos a la elección presidencial de 1970, la cinta entrelaza los sucesos públicos y políticos con la vivencia del proceso que efectúa el protagonista. El crítico de El Mercurio Antonio Romera aludió al aspecto narrativo del filme y su compleja estructura diegética, que intercala tres temporalidades históricas (presente de la narración, 1970; juventud, c. 1947, "ley maldita" y proscripción del P.C.; infancia, c. 1937, tiempos del Frente Popular) articuladas desde la subjetividad del personaje principal. El paso de una a otra se significa utilizando tonos sepia para el pasado y color para el presente. Para Romera, "los saltos en estas tres etapas son bruscos", en cambio, "los episodios incidentales, como las represiones de la policía política, asaltos, robo de un auto, muerte de un carabinero y asesinato del general Schneider, están revividos fílmicamente con excelente vigor y acento". Era por esto que, añadía, el correcto desempeño formal se empañaba "por la escasa claridad de la historia, por lo confuso del desarrollo y por lo enigmático de lo que sucede [...]. Entre realidad y ficción las cosas tratan de fundirse. Pero las primeras secuencias exigen un esfuerzo del espectador" (Critilo, 1971:34).

El relato que propone el filme es efectivamente complejo. No sólo están en juego los tres tiempos históricos referidos. Cuanto sucede en el presente se compone a su vez de tres cauces paralelos: el del trío protagónico, el de la alta política, y el del grupo del M.I.R. Pero la lectura de los contenidos más evidentes del largometraje no podía resultar algo muy complicado para el público de 1971. Si hay una exigencia para los espectadores, proviene de su trama, hilvanada con saltos temporales, elipsis y una narración fragmentada. Aunque al nivel de la anécdota política que expone, la cinta no hace más que referir hechos contingentes, el principal de los cuales es la elección presidencial.

El problema mayor, y donde reside asimismo la riqueza del filme, es que 
la exposición de tales hechos provenientes de la realidad extrafílmica, son integrados a la cinta mediante elementos provenientes de lo real. En algunas secuencias Soto utilizó fotografías tomadas de la prensa, a las que añadió como banda sonora las emisiones radiales y el registro del audio directo de ciertos sucesos, como el día de la votación y la posterior ratificación del veredicto por el Congreso Pleno. Corresponden a recursos formales tomados prestados del documental que, traspuestos en esta cinta de ficción sobre un presente muy realista, trastocan ambos campos cinematográficos. Esos hiatos del relato sirven para separar lo ficticio de lo real, distanciando al espectador de la mimesis realista. Aunque, paradójicamente, fungen al mismo tiempo de puente entre uno y otro plano existencial, al desdibujar los límites que convencionalmente se atribuyen al cine documental y al de ficción (Weinrichter, 2005). Así, con verdaderas citas que refieren a la realidad extradiegética, se incrementó la presencia de ésta en un relato proveniente de la ficción.

En La metamorfosis del jefe de la policía política, Soto volvió sobre el mismo problema, ahondando su experimentación en torno a los límites atribuidos a la representación de lo real y de lo imaginado en el cine, aunque con menor resultado de conjunto. Lo que en Voto+Fusil había sido una búsqueda formal sutil que eclosionaba sólo en algunas escenas, en su siguiente filme resulta ser una constante de principio a fin.

La primera escena corresponde a una entrevista televisiva al protagonista, en su calidad de jefe policial, sobre el escándalo de los "documentos de la ITT", un hecho real que tuvo lugar meses antes. El procedimiento cinematográfico que utiliza Soto en esta escena introductoria consiste en que los temas aludidos por los personajes son referidos visualmente a través de imágenes de archivo y fotografías de algunos de los pasajes destacados del informe de la compañía transnacional (Bolzoni, 1974:62). El director recurre nuevamente a las claves documentales para insertarlas en el mundo narrativo por él creado. Pero en esta escena en particular, esto tiene un doble significado: en la medida en que temas e imágenes se enmarcan en una entrevista televisiva, lo que ve el espectador de la cinta es el material producido por la T.V. El cineasta juega con los niveles de realidad, de forma tal que su película "filma" lo que está apareciendo en un canal de televisión inventado, de un mundo también inventado, pero cuyos referentes son reales.

El paso exploratorio que avanzó Helvio Soto en este largometraje fue otorgarle un mayor estatuto de veracidad al relato, yuxtaponiendo secuencias por entero documentales a las escenas de ficción. Esto deriva de un manejo un tanto forzado del guión -creado por el mismo Soto, al igual

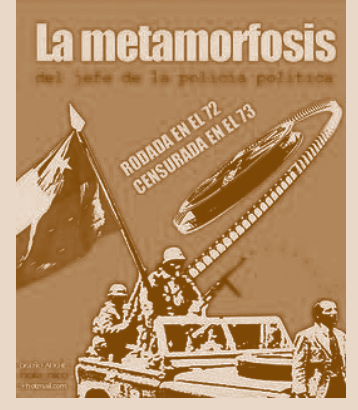

$23 \quad$\begin{tabular}{|l} 
Atenea 508 \\
II Sem. 2013
\end{tabular} 
que en sus otros largometrajes-, que lleva al protagonista a asistir o participar, dado su cargo, en hechos efectivamente acaecidos. Así, cuando revisa la filmación de una de las manifestaciones organizadas por la oposición al gobierno, donde un registro documental muestra el desfile de las fuerzas de choque de la derecha y grupos de mujeres marchando con sus cacerolas.

Otra secuencia relata la dura represión policial contra un grupo de pobladores sin vivienda que había ocupado ilegalmente un predio suburbano. Fue un hecho real también, que contrarió a varios personeros de la U.P. Esa es la posición que asume el ficticio jefe de la policía política. Después de unas líneas que éste dice, la película muestra escenas documentales rodadas en las poblaciones de Santiago. Visualmente recuerda los materiales que Patricio Guzmán utilizó para La Batalla de Chile. También el nivel del debate de los pobladores, donde se advierte la conciencia de la radicalización del proceso y la articulación del poder popular. En estos y otros pasajes, para diferenciar lo propiamente ficticio de aquello que no lo es, el director presenta las secuencias reseñadas en sepia.

Las yuxtaposiciones y préstamos de recursos documentales terminan de anudarse en la escena final de la cinta, donde los personajes inventados se fusionan con el contexto extrafílmico. En la última discusión entre el protagonista y su colega funcionario de gobierno, el jefe policial argumenta que quienes harán la revolución serán los sectores populares, desde sus necesidades inmediatas, que no admiten la dilación que impone la clase política. Su colega se muestra en desacuerdo y hasta contrariado. Después de la discusión, la cámara acompaña a este último hacia la calle. Afuera, el personaje se cruza con más y más personas que portan banderas chilenas. La toma se abre y muestra que gente de todas las edades se dirige a una gran concentración, una muestra de apoyo al "compañero Presidente". Se trata de una toma documental. El funcionario -ficticio-, todavía distinguible entre la multitud -real-, se confunde entre banderas y pancartas. Mientras todos avanzan hacia la izquierda de la imagen, él se dirige en contra, hasta que sale de cuadro.

El filme fue vilipendiado más por su estreno inoportuno, a pocos meses del 11 de septiembre, que por su propuesta cinematográfica (Mouesca, 1988: 45). Ésta quedó subsumida en algunos comentarios que resaltaron las similitudes del trabajo de Soto con el cine político europeo entonces en boga. Se dijo que la cinta apostaba a la política ficción y a la exposición de los mecanismos del poder tras bambalinas, un mundo conspirativo y opresivo para los habitantes normales de un mundo polarizado por la guerra fría. Este mismo tono en el que descansaba la trama fue asociado al cine de 
Constantin Costa-Gavras, quien recibió mucha atención en la época por haber rodado en Chile Estado de sitio y por haber sido el presentador de Voto+ Fusil en Cannes (Primer Plano, 1972c).

Pero si bien es cierto que algo de la influencia del realizador de origen griego alienta en el cine que Helvio Soto realizó durante la U. P., ésta fue acotada y no explica el fondo de su propuesta ni el escozor que ella generó en el medio local. Había, por lo demás, un referente más cercano de este tipo de hibridaciones, como Memorias del subdesarrollo (1968), del cubano Tomás Gutiérrez Alea, que no sólo utiliza secuencias documentales de un modo muy similar, confundiendo planos de la realidad, sino que además ofrece una mirada distanciada de la revolución siguiendo los pasos de un intelectual burgués.

Al reseñar Voto+Fusil, Sergio Salinas apuntó que era "híbrido y confuso" y que, como proponía la cinta al comenzar, "nada es completamente ficticio ni definitivamente auténtico, ya que, no bastará para restituir la realidad insertar unas cuantas fotos fijas o unos pocos planos filmados de los hechos mismos entre otros sucesos inventados [...]. Una posibilidad más seria era realizar un documental propiamente dicho, un filme de montaje, utilizando los documentos y materiales disponibles" (1972: 74). Es un malestar que está en directa relación con los préstamos que Soto tomó de los dos grandes géneros cinematográficos. Aunque los límites entre cine argumental y documental nunca han sido claros, ya que no están dados de antemano por una necesaria diferencia ontológica de los materiales con los que se elabora cada uno, sino por la asignación de campos de la realidad diferenciados a priori (Weinrichter, 2005). La ecuación entre documental y realidad no es más que una convención, como pone de manifiesto el propio Salinas al reprochar que no se hubiera hecho un "filme de montaje": "el último tercio del filme es aún más discutible, ya que no se pretende la elaboración de un verdadero documental, de utilizar esa inapreciable posibilidad del cine como instrumento de testimonio, que aprehende y registra la realidad para rescatar un instante del tiempo, de la historia, de otro modo irrecuperable [...]" (74).

Había, pese a este tipo de objeciones, un terreno abonado para atreverse en la búsqueda de nuevos canales expresivos. Lo habían preparado las cintas y textos teóricos de varios cineastas latinoamericanos, entre otros, Fernando Birri, quien hizo explícito el tratamiento narrativo otorgado al material proveniente del mundo social (López, 1990). Según resaltaron Getino y Velleggia (2002), uno de los rasgos determinantes de la cinematografía desarrollada desde la década del 60 en nuestro continente fue el 
cuestionamiento de la dramaturgia del cine clásico de influencia hollywoodense y su adaptación acrítica del realismo literario como base del guión del largometraje argumental.

En términos del debate sobre qué constituía un cine revolucionario, el ambiente cinéfilo chileno también propició la experimentación. Sin que pudieran llegar a una conclusión, las opiniones tendieron a la apertura de las herramientas de las que podía echarse mano (aun cuando, retrospectivamente, sus mismos emisores vieron en ello un costo político). Littin, por ejemplo, indicó "que puede concebirse el caso de que se transmitan contenidos revolucionarios empleando recursos añejos, reaccionarios", aunque "en tal caso no habrá, ciertamente, cine revolucionario" (Primer Plano, 1972b: 9).

El problema radicó en construir una serie de significantes cinematográficos inéditos, acordes a una realidad histórica asimismo inédita, en un país carente de cultura fílmica nacional y cuyos realizadores no contaban con un aprendizaje largo, más que el de la práctica adquirida en ese instante. A ello se sumaba, en opinión de Helvio Soto, el acostumbramiento de los espectadores al "gran stock de recursos elaborados en Europa y Norteamérica". Frente a éstos, aquéllos elaborados por las nuevas cinematografías del continente, "muchas veces son incomprendidos por las masas" (Primer Plano, 1972a: 9).

Otros, como el cineasta y crítico José Román, insistieron en la necesaria deconstrucción de ese acervo fílmico canónico como paso previo a la forja de uno nuevo. De lo contrario, se caía en "la tentación 'rupturista' [que] es la que mayor incentivo ofrece a los nuevos realizadores", quienes, abjurando "de un 'lenguaje convencional', cuya mecánica frecuentemente desconocen o de un 'cine académico' que rechazan sin indagar en los mecanismos que lo hacen accesible a las grandes masas", los podía llevar a hacer "obras que constituyen, en el mejor de los casos, experiencias fallidas en el plano de la comunicación" (cit. en Silva, 1972).

Para un documentalista como Patricio Guzmán, que vivió como cierta la tarea de registrar en la cámara un proceso histórico en aceleración creciente, los límites del lenguaje fílmico estaban abiertos. "Yo creo en un tercer género entre el documental y el argumental", afirmó en 1973, agregando que "por lo demás no veo tanta diferencia entre ambos. Me parece que es perfectamente posible, y aconsejable, tomar el ritmo y la construcción dramática del argumental e insertarla en el documental" (Primer Plano, 1973: 28). El mismo Littin se había acercado a una mixtura de lenguajes en $E l$ 
Chacal de Nahueltoro, al utilizar la cámara en mano en escenas que remedan el documental y el reportaje (López, 1990).

Por otra parte, en cuanto a la movilización del espectador y su propuesta de obra abierta o inacabada -claro vínculo con la literatura de la época-, que llevaba a que el público decidiera entre mentira y verdad, la película de Soto encontró eco incluso en el trabajo de sus colegas documentalistas. Como Patricio Guzmán afirmó respecto a El primer año: "La película es más una observación que un análisis. Prácticamente no hay análisis y es el espectador quien debe sacar las conclusiones. La película solamente muestra, llevando al extremo un método que seguramente constituye un defecto. Este método, sin embargo, se aviene mucho con la forma de trabajo que propongo en el sentido de que la película se haga, se monte y se exhiba rápidamente" (Primer Plano, 1973: 29).

En el caso del cine de Helvio Soto había una urgencia muy parecida. La puesta en tensión de los límites entre documental y ficción, fundada en el cuestionamiento de las premisas en que ambos géneros descansaban, le permitió crear otro horizonte de observación del proceso histórico que vivía el país. Según declaró a la revista Primer Plano (1972a): "A fines del año pasado pensé que en Chile podría pasar cualquier cosa. Y como el compromiso con la realidad comienza cuando empezamos a interpretar esa realidad, creí necesario rodar un documento de cualquier naturaleza que dejara constancia, desde determinado punto de vista, de lo que estaba ocurriendo. Todo lo hicimos a gran velocidad. A fines de septiembre, después del triunfo de Allende en las urnas, estábamos con la mitad del guión hecho y la otra mitad totalmente atento a lo que viniera" (20). Como se aprecia, en la intención del director y su equipo, así como entre los actores culturales chilenos, había conciencia de lo histórico del momento que vivían. La clase de cine que llevaron a la práctica fue el que les demandaba un país en plena transformación y cuyos desplazamientos lo convierten en un ejercicio de autocomprensión, al tiempo que en una temprana escritura fílmica de la historia.

\section{REFERENCIAS}

Bolzoni, F. (1974). El cine de Allende. Valencia: Fernando Torres editor.

Bowen, M. (2008). "El proyecto sociocultural de la izquierda chilena durante la Unidad Popular. Crítica, verdad e inmunología política”. Nuevo Mundo 
Mundos Nuevos [En línea], puesto en línea el 21 de enero 2008. URL: http:// nuevomundo.revues.org/13732.

Cavallo, A. y Díaz, C. (2007). Explotados y benditos. Mito y desmitificación del cine chileno de los 60. Santiago: Uqbar Editores.

Critilo [seud. de Antonio Romera] (1971). "Voto+Fusil". El Mercurio, 13/08, 34. Ercilla (1971), "Voto más Fusil”, Ercilla, 17/08, 47.

García Espinoza, J. (1969). "Por un cine imperfecto". En Hojas de cine. Testimonios y documentos del Nuevo Cine Latinoamericano, Vol. III. México D.F.: SEP - UAM - Fundación Mexicana de Cineastas, 1988, 63-77.

Getino, O. y Velleggia, S. (2002). El cine de 'las historias de la revolución'. Aproximación a las teorías y prácticas del cine de 'intervención politica' en América Latina (1967-1977). Buenos Aires: Grupo Editor Altamira - INCAA.

Guzmán, P. (1974). "Breve análisis del cine chileno durante el gobierno popular". En Hojas de cine. Testimonios y documentos del Nuevo Cine Latinoamericano, Vol. I. México D.F.: SEP - UAM - Fundación Mexicana de Cineastas, 1988, 331-339.

López, A. M. (1990). "At the Limits of Documentary: Hypertextual transformation and the New Latin American Cinema". En The Social Documentary in Latin America. Julianne Burton, ed. Pittsburgh: University of Pittsburgh Press, 403-432.

Mouesca, J. (1988). Plano secuencia de la memoria de Chile. Veinticinco años de cine chileno (1960-1985). Madrid: Ediciones del Litoral.

Primer Plano (1972a). "Entrevista a Helvio Soto - Para ser un cineasta revolucionario primero hay que ser un buen cineasta". Primer plano 1 (verano 1972), 4-26.

Primer Plano (1972b). "Entrevista a Miguel Littin: 'Primero hay que aprovechar el dividendo ideológico del cine”. Primer Plano 2 (otoño 1972), 4-16.

Primer Plano (1972c). "Confesiones de Costa-Gavras". Primer Plano 3 (invierno 1972), 52-60.

Primer Plano (1972d). "Entrevista a Aldo Francia - Todo cine es un engaño". Primer Plano 3 (invierno 1972), 4-17.

Primer Plano (1973). "Entrevista a Patricio Guzmán - Más vale una sólida formación política que la destreza artesanal". Primer Plano 5 (verano 1973), 19-36.

Rosenstone, R. (1997). El pasado en imágenes. El desafío del cine a nuestra idea de la historia. Barcelona: Ariel.

Salinas, S. (1972). "Voto+Fusil de Helvio Soto". Primer Plano 1 (verano), 72-75.

Silva, J. P. y Raurich, R. (2010). "Emergente, dominante y residual. Una mirada sobre la fabricación de lo popular realizada por el Nuevo Cine Chileno (1958-1973)". Aisthesis 47, 64-82.

Silva, M. (1972). "Informe sobre el Nuevo Cine Chileno. Ensayo de diagnóstico sobre una industria fracasada y sobre un movimiento de renovación con peligro de anquilosarse". Mensaje 208 (marzo), consultado en www.cinechile.cl (http://www.cinechile.cl/archivo.php?archivoid=59). 
Soto, H. (1980). "Mi aprendizaje con Caliche sangriento". Araucaria de Chile $11,144-145$.

Weinrichter, A. (2005). Desvíos de lo real: el cine de no ficción. Madrid: T\&B Editores. 